\title{
Synthesis of Phenols via Metal-Free Hydroxylation of Aryl Boronic Acids with Aqueous TBHP
}

\author{
Tanveer MahmadAlli Shaikh \\ Department of Chemistry, College of Natural \& Computational Sciences, Mekelle University, Mekelle, Ethiopia \\ Correspondence should be addressed to Tanveer MahmadAlli Shaikh; tanveerchem1@gmail.com
}

Received 16 April 2020; Revised 1 June 2020; Accepted 2 June 2020; Published 27 June 2020

Academic Editor: Toyonobu Usuki

Copyright (c) 2020 Tanveer MahmadAlli Shaikh. This is an open access article distributed under the Creative Commons Attribution License, which permits unrestricted use, distribution, and reproduction in any medium, provided the original work is properly cited.

An alternate procedure for oxidative hydroxylation of aryl boronic acids with aqueous TBHP to access phenols is described. The protocol tolerated various functional groups substituted with aromatic rings. The reaction was performed in water and free from transition metal oxidants.

\section{Introduction}

In the past few decades, phenols have received great attention in modern synthetic chemistry [1-3], since ever Runge and Laurent made the first discovery in 1834 and 1841 , respectively $[4,5]$, with regard to this motif, which is frequently found in natural products [6-8], flavonoids $[9,10]$, and pharmaceutically important compounds [11-17] associated with certain bioactivities, such as antibacterial [18-20], antifungal, antibiotic [21], anti-inflammatory $[22,23]$, antiviral $[24]$, anxiolytic $[25,26]$, and antioxidant [27-33] activities.

In addition, they serve as a powerful building block and precursor in metal-catalyzed cross-coupling reactions [34-39] and synthesis of oxy-functionalized derivatives including o-alkenyl phenols [40], benzofurans and dibenzofurans [41-44], chromanones [45], coumarins [46-49], glycosides [50], and benzolactone [51], Representative examples of commercially important drugs are presented in Figure 1. Conventional methods for the large-scale synthesis of phenols include the Hock process, diazotization of aromatic amines, and nucleophilic substitution reactions. Academicians have focused on the development of alternative approaches, for example, $\mathrm{C}-\mathrm{H}$ activation of arenes $[52,53]$ and oxidation of C-Si bonds [54] and C-halo bonds [55, 56]. Recently, the direct hydroxylation of aryl boronic acids to phenols has gained a lot of attention. In this context, a variety of oxidative methods employing metal catalysts, $\mathrm{Cu}(\mathrm{OAc})_{2}-\mathrm{H}_{2} \mathrm{O}_{2}$ [57], $\mathrm{CuSO}_{4}$-phenanthroline [58], $\mathrm{CuCl}_{2}$-micellar systems [59], $\mathrm{Cu}_{2} \mathrm{O}-\mathrm{NH}_{3}$ [60], $\quad\left[\mathrm{Ru}(\text { bpy })_{3} \mathrm{Cl}_{2}\right] \cdot 6 \mathrm{H}_{2} \mathrm{O}$ [61], $\mathrm{Al}_{2} \mathrm{O}_{3}-\mathrm{H}_{2} \mathrm{O}_{2}$ [62], and $\mathrm{H}_{3} \mathrm{BO}_{3}-\mathrm{H}_{2} \mathrm{O}_{2}$ [63] has been developed. On the other hand, the metal-free oxidative process are also competitive, Oxone [64, 65], $n \mathrm{Bu}_{4} \mathrm{NHSO}_{5}$ [66], $\mathrm{NH}_{2} \mathrm{OH}$ [67], $\mathrm{H}_{2} \mathrm{O}_{2}$ poly(N-vinylpyrrolidone) [68], $\mathrm{I}_{2}-\mathrm{H}_{2} \mathrm{O}_{2}$ [69], Amberlite IR$120-\mathrm{H}_{2} \mathrm{O}_{2}$ [70], $\mathrm{N}$-oxides [71], MCPBA [72], $\mathrm{NaClO}_{2}$ [73], photoredox catalysis $[74,75]$, electrochemical oxidation [76, 77], $\left(\mathrm{NH}_{4}\right)_{2} \mathrm{~S}_{2} \mathrm{O}_{8}$ [78], PEG-400- $\mathrm{H}_{2} \mathrm{O}_{2}$ [79], WERSA$\mathrm{H}_{2} \mathrm{O}_{2}$ [80], WEBPA- $\mathrm{H}_{2} \mathrm{O}_{2}$ [81], nanoparticles of $\mathrm{Ag}$ [82], $\mathrm{Cu}_{2} \mathrm{O}$ [83], and $\mathrm{Fe}_{2} \mathrm{O}_{3} /$ silica gel [84], and $\mathrm{TBHP} / \mathrm{Cl}_{3} \mathrm{CCN}$ [85]. Despite these efficient oxidative processes, developing a new methodology free from metal oxidants and organic solvents is highly desirable. As part of our research interest involving metal-free oxidation reactions [86], herein, a new protocol for the direct hydroxylation of aryl boronic acids with TBHP in the aqueous medium is reported (Scheme 1).

\section{Results and Discussion}

During a study of the Pd-Cu catalyzed cross-coupling reaction with phenylboronic acid as one of the components, surprisingly the reaction took a different course and resulted phenol as a new product. This unexpected product was observed after addition of aqueous TBHP as part of workup. Then, it was our interest to find detailed investigation of this 
<smiles>CC(=O)Nc1ccc(O)cc1</smiles>

Paracetamol<smiles>O=C(O)/C=C/c1ccc(O)c(O)c1</smiles>

Caffeic acid<smiles>O=C1CC(c2ccc(O)cc2)Oc2cc(O)cc(O)c21</smiles>

Apigenin<smiles>COc1cc2c(cc1O)CN(C)C[C@H]2c1ccc(O)cc1</smiles><smiles>C=CCc1ccc(O)c(OC)c1</smiles>

FIGURE 1: Bioactive compounds with phenol moiety.<smiles>[R]O[GaH]c1ccc([18OH])cc1</smiles>

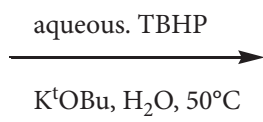<smiles>[R][C]1CCCCC1O</smiles>

Scheme 1: Hydroxylation of aryl boronic acids.

reaction. In order to find suitable reaction conditions, various reaction parameters have been considered and they are presented in Tables 1 and 2 .

Table 1 describes the solvent effect for the hydroxylation reaction. We commenced our investigation by subjecting phenylboronic acid as a model substrate and aqueous $70 \%$ TBHP as an oxidant. Traces of phenol were observed under the reaction temperature of $0-25^{\circ} \mathrm{C}$ in the presence of $\mathrm{Cs}_{2} \mathrm{CO}_{3}$ as a base and THF solvent (Table 1, entries 1-2). When the reaction was performed in a $1: 1$ mixture of THF: $\mathrm{H}_{2} \mathrm{O}$ solvent, to our surprise, only $22 \%$ of phenol was observed (Table 1, entry 3 ). However, combination of acetonitrile or dimethylformamide with water did not favor this hydroxylation process, although the temperature was raised to $70^{\circ} \mathrm{C}$ (entries $4-5$ ). When the reaction was stirred in water as solvent, $47 \%$ of yield of the product was observed at $70^{\circ} \mathrm{C}$ (entry 8). It is important to conclude that water is necessary to form homogeneous reaction mixture.

Considering the role of the oxidant and base in the hydroxylation process, we then studied ratios of the oxidant and base, and the findings are outlined in Table 2. An initial study was conducted using $2: 1$ ratio of the oxidant and base in water solvent heated to $70^{\circ} \mathrm{C}$ (Table 2, entry 2). Although $50 \%$ of the desired product was obtained, substantial amount of unreactive phenylboronic acid was isolated. Changing the temperature and base $\mathrm{K}_{2} \mathrm{CO}_{3}$ did not favor the oxidative process (entries 3-4). On the other hand, organic bases such as pyridine, triethyl amine, and diethyl amine completely ruled out hydroxylation (entries 5-7). To our surprise, an improved yield of phenol (76\%) was observed with $\mathrm{NaOH}$ (entry 8). Variations in temperature $\left(25-80^{\circ} \mathrm{C}\right)$ resulted $45-60 \%$ yield of the product (entries 9-10). The control experiment either in the absence of an oxidant or base failed
TABle 1: Solvent study: hydroxylation of phenylboronic acid ${ }^{\mathrm{a}}$.

\begin{tabular}{lcccc}
\hline Entry & Solvent & Temp. $\left({ }^{\circ} \mathrm{C}\right)$ & Time $(\mathrm{h})$ & Yield $(\%)^{\mathrm{b}, \mathrm{c}}$ \\
\hline 1 & THF & 0 & 1 & NR \\
2 & THF & 25 & 1 & Trace \\
3 & THF $: \mathrm{H}_{2} \mathrm{O}$ & 25 & 1 & 22 \\
4 & $\mathrm{CH}_{3} \mathrm{CN}: \mathrm{H}_{2} \mathrm{O}$ & 25 & 3 & 10 \\
5 & $\mathrm{DMF}: \mathrm{H}_{2} \mathrm{O}$ & 70 & 3 & $>5^{\mathrm{d}}$ \\
6 & $\mathrm{THF}: \mathrm{H}_{2} \mathrm{O}$ & 50 & 3 & 25 \\
7 & $\mathrm{H}_{2} \mathrm{O}$ & 25 & 1 & 18 \\
8 & $\mathrm{H}_{2} \mathrm{O}$ & 70 & 3 & 47 \\
\hline
\end{tabular}

${ }^{a}$ Reaction conditions: phenylboronic acid $(1 \mathrm{mmol})$, aqueous TBHP $(1 \mathrm{mmol}), \mathrm{Cs}_{2} \mathrm{CO}_{3}(0.5 \mathrm{mmol})$, and solvent stirred at designated temperature and time; ${ }^{b}$ isolated yield; ${ }^{c}$ products were characterized by MP, FTIR,

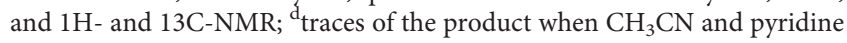
solvents were used.

to give any product (entries 11-12). A significant improvement noticed with combination of aqueous TBHP and potassium tert-butoxide as an effective base in water provided high yield $(92 \%)$ of phenol at $50^{\circ} \mathrm{C}$ (entry 14$)$. Thus, the optimized reaction conditions for this hydroxylation process involved phenylboronic acid ( $1 \mathrm{mmol})$, aqueous TBHP (2 mmol), TBHP (2), $\mathrm{KO}^{\mathrm{t}} \mathrm{Bu}(1 \mathrm{mmol})$, and $\mathrm{H}_{2} \mathrm{O}(1 \mathrm{~mL})$ heated to $50^{\circ} \mathrm{C}$ (entry 14 ).

Having the optimized reaction conditions in hand, we then pursued the scope of this hydroxylation process using a variety of substituted aryl boronic acids, and the results are presented in Table 3. Initially, the substrates bearing halides such as bromo, chloro, and iodo were tested, and as expected, the corresponding hydroxylated product was obtained in excellent yields (Table 3, entries 2-4). The aryl substitution did not alter the reaction, for example, the reaction of 4-phenyl-, 2-phenyl-, and naphthyl-boronic acids resulted 4-phenylphenol, 2-phenylphenol, and 2naphthol in $90-92 \%$ yields, respectively (entries 5-7). Simple methyl groups at para positions proceed smoothly to give para-Cresol in $89 \%$ yields (entry 8 ). Some limitations appear when a strong electron-donating group such as para-methoxy boronic acid was subjected to the 
TABLE 2: Optimization of hydroxylation parameters ${ }^{\mathrm{a}}$.

\begin{tabular}{|c|c|c|c|c|c|}
\hline Entry & Oxidant (equiv.) & Base (equiv.) & Temp. $\left({ }^{\circ} \mathrm{C}\right)$ & Time (h) & Yield $(\%)^{\mathrm{b}, \mathrm{c}}$ \\
\hline 1 & TBHP (1) & $\mathrm{Cs}_{2} \mathrm{CO}_{3}(1)$ & 70 & 3 & 47 \\
\hline 2 & TBHP (2) & $\mathrm{Cs}_{2} \mathrm{CO}_{3}(1)$ & 70 & 5 & $50^{\mathrm{d}}$ \\
\hline 3 & TBHP (2) & $\mathrm{K}_{2} \mathrm{CO}_{3}(0.5)$ & 60 & 5 & 25 \\
\hline 4 & TBHP (2) & $\mathrm{K}_{2} \mathrm{CO}_{3}$ & 25 & 5 & 10 \\
\hline 5 & TBHP (2) & Pyridine (1) & 60 & 10 & NR \\
\hline 6 & TBHP (2) & $\mathrm{Et}_{3} \mathrm{~N}$ & 60 & 5 & NR \\
\hline 7 & TBHP (2) & $\mathrm{Et}_{2} \mathrm{NH}(1)$ & 60 & 5 & 22 \\
\hline 8 & TBHP (2) & $\mathrm{NaOH}(1)$ & 50 & 5 & 76 \\
\hline 9 & TBHP (2) & $\mathrm{NaOH}(1)$ & 25 & 5 & 45 \\
\hline 10 & TBHP (2) & $\mathrm{NaOH}(1)$ & 80 & 2 & 60 \\
\hline 11 & - & $\mathrm{NaOH}(1)$ & 50 & 5 & NR \\
\hline 12 & TBHP (2) & - & 50 & 5 & Traces \\
\hline 13 & TBHP (2) & $\mathrm{KOH}(1)$ & 50 & 5 & 80 \\
\hline 14 & TBHP (2) & $\mathrm{KO}^{t} \mathrm{Bu}(1)$ & 50 & 5 & $92(87)^{\mathrm{e}}$ \\
\hline
\end{tabular}

${ }^{a}$ Reaction conditions: phenylboronic acid (1 mmol), aqueous TBHP base, and water $(1 \mathrm{~mL})$ stirred at designated temperature and time; ${ }^{\mathrm{b}}$ Isolated yield after workup; ${ }^{c}$ Products were characterized by MP, FTIR, and ${ }^{1} \mathrm{H}$ - and ${ }^{13} \mathrm{C}-\mathrm{NMR} ;{ }^{\mathrm{d}}$ THF was added to mix reactants. ${ }^{e}$ Yield after 2 hours.

TABLE 3: Substrate scope for the direct hydroxylation of aryl boronic acids ${ }^{\mathrm{a}}$.

\begin{tabular}{|c|c|c|c|}
\hline Entry & Substrate & Product & Yield $(\%)^{\mathrm{b}, \mathrm{c}}$ \\
\hline 1 & & & 92 \\
\hline 2 & & & 90 \\
\hline 3 & & & 93 \\
\hline 4 & & & 87 \\
\hline 5 & & & 92 \\
\hline 6 & & $\mathrm{Ph}$ & 90 \\
\hline 7 & & & 85 \\
\hline 8 & & & 89 \\
\hline 9 & & & 60 \\
\hline 10 & & & 95 \\
\hline 11 & & & 47 \\
\hline 12 & & & $\mathrm{nd}^{\mathrm{d}}$ \\
\hline 13 & & & $10^{\mathrm{e}}$ \\
\hline
\end{tabular}

${ }^{\mathrm{a}}$ Reaction conditions: aryl boronic acid $(1 \mathrm{mmol})$, aqueous TBHP $(2 \mathrm{mmol})$, TBHP $(2 \mathrm{mmol}), \mathrm{KO}^{\mathrm{t}} \mathrm{Bu}(1 \mathrm{mmol})$, and $\mathrm{H}_{2} \mathrm{O}(1 \mathrm{~mL}), 50^{\circ} \mathrm{C}$; ${ }^{b}$ isolated yield; ${ }^{c}$ products were characterized by MP, FTIR, and ${ }^{1} \mathrm{H}$ - and ${ }^{13} \mathrm{C}-\mathrm{NMR}$; ${ }^{\mathrm{d}}$ the desired product was not isolated; ${ }^{\mathrm{e}} \mathrm{Characterized}$ by FTIR. 
hydroxylation; the corresponding para methoxyphenol was isolated in $60 \%$ yield (entry 9), in addition to the side product because of the possibility of overoxidation. The presence of a strong electron-withdrawing substituent $-\mathrm{NO}_{2}$ on aryl boronic acid quantitatively converted to the paranitrophenol in excellent yield (entry 10). However, the expected 4-hydroxy-methyl-benzoate (entry 11) could be observed only in moderate yield when ester-boronic acid was tested; the corresponding acid was also formed during the course of hydroxylation.

\section{Conclusion}

An alternate method for the direct hydroxylation of aryl boronic acid to phenol promoted by aqueous TBHP as an oxidant using metal- and solvent-free conditions has been described. The products were obtained in good to excellent yields. It is important to note that the reaction works only with aryl boronic acids and not with heteroaryl or basesensitive functional groups. The methodology is free from chromatographic purification because the desired products were obtained in pure form after acidic workup. Since this protocol is free from chromatographic purification, it could be extended for large-scale synthesis.

\section{Materials and Methods}

FTIR spectra of the synthesized compounds were recorded on a Shimadzu 4000 instrument using the $\mathrm{KBr}$ pellet within the range of $400 \pm 10$ to $4000 \pm 10 \mathrm{~cm}^{-1}$. ${ }^{1} \mathrm{H}-\mathrm{NMR}$ and ${ }^{13} \mathrm{C}$ NMR spectra of all compounds were recorded on a Bruker NMR spectrometer using 400 and $100 \mathrm{MHz}$, respectively. Analysis of NMR was carried out using deuterated solvent $\mathrm{CDCl}_{3}$ and DMSO TMS as an internal standard. Chemical shift values are expressed in $\delta$ (ppm).

All the starting materials, chemicals, and reagents were commercially available and used without further purification unless otherwise stated. TBHP was purchased from Merck, while potassium tert-butoxide and boronic acids were procured from Sigma Aldrich and Rankem, India, respectively. TLC plates and commercial grade solvents such as ethyl acetate and petroleum ether were purchased from Rankem, India. Other reagents such as $\mathrm{Cs}_{2} \mathrm{CO}_{3}, \mathrm{~K}_{2} \mathrm{CO}_{3}$, $\mathrm{KOH}, \mathrm{NaOH}, \mathrm{CH}_{3} \mathrm{CN}$, and DMF are of AR grade and from SD Fine, India.

4.1. General Procedure for Hydroxylation. To a $5 \mathrm{~mL}$ screw top sample vial equipped with a magnetic stirrer bar, phenylboronic acid $(0.2 \mathrm{mmol}, 1$ equiv), water $(1 \mathrm{~mL})$, and potassium tert-butoxide were introduced and stirred at room temperature. To this mixture, $70 \%$ aqueous TBHP was added with continuous stirring, and the reaction mixture was further heated at $50{ }^{\circ} \mathrm{C}$ for $5 \mathrm{~h}$. The formation of phenol was monitored with the help of TLC. After completion of the reaction, the vial was cooled to room temperature, followed by addition of aqueous $6 \mathrm{~N} \mathrm{HCl}$. The resultant mixture was extracted with ethyl acetate. The organic layer was washed with cold water and then dried over anhydrous sodium sulphate. The ethyl acetate was evaporated using a rotary evaporator to yield the corresponding phenol in pure form.

4.2. Spectral Data. Phenol (Table 2, entry 1): colorless solid; MP 41-42 ${ }^{\circ} \mathrm{C}$ (lit. 41-42 ${ }^{\circ} \mathrm{C}$ ); FTIR (KBr, $\mathrm{cm}^{-1}$ ) 692, 815, 1065, $1220,1365,1470,1592,1920,2350$, and $3325 ;{ }^{1} \mathrm{H}-\mathrm{NMR}$ $\left(400 \mathrm{MHz}, \mathrm{CDCl}_{3}\right): \delta 7.28-7.22(\mathrm{~m}, 2 \mathrm{H}), 6.96-6.91(\mathrm{~m}, 1 \mathrm{H})$, 6.85-6.82 (m, 2H), and $5.03(\mathrm{~s}, 1 \mathrm{H}) ;{ }^{13} \mathrm{C}-\mathrm{NMR}(100 \mathrm{MHz}$, $\left.\mathrm{CDCl}_{3}\right): \delta 155.0,129.7,121.0$, and 115.3.

4-Bromophenol (Table 2, entry 2): colorless solid; MP 60-62 ${ }^{\circ}$; FTIR $\left(\mathrm{KBr}, \mathrm{cm}^{-1}\right)$ 604, 810, 1030, 1207, 1405, 1500, 1595, and 3402; ${ }^{1} \mathrm{H}-\mathrm{NMR}\left(400 \mathrm{MHz}, \mathrm{CDCl}_{3}\right): \delta 5.10(\mathrm{br} \mathrm{s}$, $1 \mathrm{H}), 6.71(\mathrm{~d}, J=8.5 \mathrm{~Hz}, 2 \mathrm{H})$, and $7.30(\mathrm{~d}, 2 \mathrm{H} \mathrm{J}=8.5 \mathrm{~Hz}, 2 \mathrm{H})$; ${ }^{13} \mathrm{C}-\mathrm{NMR}\left(100 \mathrm{MHz}, \mathrm{CDCl}_{3}\right): \delta 113.1,117.3,132.7$, and 154.4 .

4-Chlorophenol (Table 2, entry 3): white solid; MP 44-45 ${ }^{\circ}$; FTIR $\left(\mathrm{KBr}, \mathrm{cm}^{-1}\right)$ 635, 715, 820, 1089, 1220, 1352, 1490, 2850, 2900, 3240, and 3335; ${ }^{1} \mathrm{H}-\mathrm{NMR}(400 \mathrm{MHz}$, $\left.\mathrm{CDCl}_{3}\right): \delta 4.76($ br s, $1 \mathrm{H}), 6.73(\mathrm{~d}, J=8.5,2 \mathrm{H})$, and $7.20(\mathrm{~d}$, $J=8.5,2 \mathrm{H}) ;{ }^{13} \mathrm{C}-\mathrm{NMR}\left(100 \mathrm{MHz}, \mathrm{CDCl}_{3}\right): \delta 116.2,125.3$, 129.2, and 153.2.

4-Iodophenol (Table 2, entry 4): FTIR $\left(\mathrm{KBr}, \mathrm{cm}^{-1}\right)$ 802, $1001,1202,1218,1410,1442,1590$, and $3395 ;{ }^{1} \mathrm{H}-\mathrm{NMR}$ $\left(400 \mathrm{MHz}, \mathrm{CDCl}_{3}\right): \delta 4.87$ (br s, $\left.1 \mathrm{H}\right), 6.55-6.61(\mathrm{~m}, 2 \mathrm{H})$, and 7.45-7.51 (m, 2H); ${ }^{13} \mathrm{C}-\mathrm{NMR}\left(100 \mathrm{MHz}, \mathrm{CDCl}_{3}\right): \delta$ 82.6, 118.1, 138.5, and 155.2.

4-Phenylphenol (Table 2, entry 5): yellow-brown solid; MP $165-167^{\circ} \mathrm{C}$; FTIR $\left(\mathrm{KBr}, \mathrm{cm}^{-1}\right)$ 640, 750, 810, 1195, 1225, 1370, 1440, 1510, 1600, 1605, 3005, 3010, and 3395; ${ }^{1} \mathrm{H}-\mathrm{NMR}$ $\left(400 \mathrm{MHz}, \mathrm{CDCl}_{3}: \mathrm{DMSO}-\mathrm{d}_{6}\right): \delta 6.78(\mathrm{dd}, J=6.0,2.0,2 \mathrm{H})$, $7.16-7.20(\mathrm{~m}, 1 \mathrm{H}), 7.30(\mathrm{dd}, J=6.0,2.0,2 \mathrm{H}), 7.41(\mathrm{dd}, J=8.0$, $2.0,2 \mathrm{H})$, and $7.45(\mathrm{~d}, J=5.0,2 \mathrm{H}) ;{ }^{13} \mathrm{C}-\mathrm{NMR}(100 \mathrm{MHz}$, $\mathrm{CDCl}_{3}:$ DMSO-d $\left.{ }_{6}\right): \delta 116.4,127.2,128.8,129.5,133.5,142.0$, and 158.0.

2-Phenylphenol (Table 2, entry 6): FTIR $\left(\mathrm{KBr}, \mathrm{cm}^{-1}\right)$ $696,745,805,1175,1405,1425,1596,3012,3020,3420$, and 3521; ${ }^{1} \mathrm{H}-\mathrm{NMR}\left(400 \mathrm{MHz}, \mathrm{CDCl}_{3}\right): \delta 4.96$ (br s, $\left.1 \mathrm{H}\right)$, 6.92-7.02 (m, 2H), 7.20-7.29 (m, 2H), 7.34-7.40 (m, 1H), and $7.43-7.50(\mathrm{~m}, 4 \mathrm{H}) ;{ }^{13} \mathrm{C}-\mathrm{NMR}\left(100 \mathrm{MHz}, \mathrm{CDCl}_{3}\right): \delta$ $116.0,120.9,127.8,128.0,129.1,129.1,129.2,130.2,137.0$, and 152.2 .

2-Naphthalenol (Table 2, entry 7): white solid; MP 122-124 ${ }^{\circ}$; FTIR $\left(\mathrm{KBr}, \mathrm{cm}^{-1}\right) 720,805,815,940,1180,1395$, 1600, and 3240; ${ }^{1} \mathrm{H}-\mathrm{NMR}\left(400 \mathrm{MHz}, \mathrm{CDCl}_{3}\right): \delta 5.02$ (br s, $1 \mathrm{H}), 7.02-7.10(\mathrm{~m}, 2 \mathrm{H}), 7.24-7.29(\mathrm{~m}, 1 \mathrm{H}), 7.38$ (d, J=7.2, $1 \mathrm{H}), 7.62(\mathrm{~d}, J=8.3,1 \mathrm{H})$, and $7.76-7.71(\mathrm{~m}, 2 \mathrm{H}) ;{ }^{13} \mathrm{C}-\mathrm{NMR}$ $\left(100 \mathrm{MHz}, \mathrm{CDCl}_{3}\right): \delta 109.0,117.2,123.2,126.0,126.2,127.3$, $128.5,129.6,134.1$, and 153.0.

P-Cresol (Table 2, entry 8): FTIR $\left(\mathrm{KBr}, \mathrm{cm}^{-1}\right) 725,925$, $1235,1260,1461,1610,1700,2545,2920$, and $3345 ;{ }^{1} \mathrm{H}-\mathrm{NMR}$ $\left(400 \mathrm{MHz}, \mathrm{CDCl}_{3}\right): \delta 2.24(\mathrm{~s}, 3 \mathrm{H}), 4.66$ (br s, $\left.1 \mathrm{H}\right), 6.70(\mathrm{~d}$, $J=8.5 \mathrm{~Hz}, 2 \mathrm{H})$, and $7.05(\mathrm{~d}, J=8.4 \mathrm{~Hz}, 2 \mathrm{H}) ;{ }^{13} \mathrm{C}-\mathrm{NMR}$ $\left(100 \mathrm{MHz}, \mathrm{CDCl}_{3}\right): \delta 20.2,115.0,130.1,130.4$, and 153.1 .

4-Methoxyphenol (Table 2, entry 9): colorless; FTIR $\left(\mathrm{KBr}, \mathrm{cm}^{-1}\right) 725,805,1030,1175,1225,1432,1602,2830$, 2952, and 3375; ${ }^{1} \mathrm{H}-\mathrm{NMR}\left(400 \mathrm{MHz}, \mathrm{CDCl}_{3}\right): \delta 3.72(\mathrm{~s}, 3 \mathrm{H})$, 4.75 (br s, $1 \mathrm{H})$, and $6.73-6.80(\mathrm{~m}, 4 \mathrm{H}) ;{ }^{13} \mathrm{C}-\mathrm{NMR}(100 \mathrm{MHz}$, $\left.\mathrm{CDCl}_{3}\right): \delta 55.7,115.0,116.2,149.0$, and 153.2. 
4-Nitrophenol (Table 2, entry 10): yellow solid; MP 111-114 ${ }^{\circ} \mathrm{C}$; FTIR $\left(\mathrm{KBr}, \mathrm{cm}^{-1}\right) 735,922,1245,1352,1545$, 1605, 1697, 2535, 2915, and 3340; ${ }^{1} \mathrm{H}-\mathrm{NMR}(400 \mathrm{MHz}$, $\left.\mathrm{CDCl}_{3}\right): \delta 6.73-6.76(\mathrm{~m}, 2 \mathrm{H})$ and $7.93-7.97(\mathrm{~m}, 2 \mathrm{H}) ;{ }^{13} \mathrm{C}-$ NMR $\left(100 \mathrm{MHz}, \mathrm{CDCl}_{3}\right): \delta 116.2,126.1,141.2$, and 164.7.

4-Hydroxybenzoic acid (Table 2, entry 11): white solid; MP $215-217^{\circ} \mathrm{C}$; FTIR $\left(\mathrm{KBr}, \mathrm{cm}^{-1}\right) 730,850,948,1135,1220$, $1295,1305,1415,1580,1603,1700,2530,2640$, and 3395 ; ${ }^{1} \mathrm{H}-\mathrm{NMR}\left(400 \mathrm{MHz}, \mathrm{CDCl}_{3}\right): \delta 6.65-6.70(\mathrm{~m}, 2 \mathrm{H})$ and 7.71-7.76 (m, 2H); ${ }^{13} \mathrm{C}-\mathrm{NMR}\left(100 \mathrm{MHz}, \mathrm{CDCl}_{3}\right): \delta$ 116.0, $122.4,133.2,163.0$, and 170.0.

\section{Data Availability}

The data used to support the findings of this study are included within the article.

\section{Conflicts of Interest}

The author declares that there are no conflicts of interest.

\section{Acknowledgments}

The author gratefully thanks the Department of Chemistry and College of Natural and Computation Science, Mekelle University, for supporting this work.

\section{References}

[1] N. Mobinikhaledi, J. H. Foroughifar, and Fathinejad, "Metalorganic and nano metal chemistry," vol. 38, p. 428, 2008.

[2] Z. Rappoport, The Chemistry of Phenols, Wiley-VCH, Weinheim, Germany, 2003.

[3] M. Tobisu and N. Chatani, "Nickel-catalyzed cross-coupling reactions of unreactive phenolic electrophiles via C-O bond activation," Topics in Current Chemistry, vol. 41, p. 374, 2016.

[4] F. F. Runge, "Ueber einige produkte der Steinkohlendestillation," Annalen der Physik und Chemie, vol. 107, no. 5, pp. 65-78, 1834.

[5] A. Laurent, "Mémoire sur le phényle et ses dérivés," Annales de Chimie et de Physique, vol. 3, pp. 195-228, 1841.

[6] G. M. Keserü and M. Nógrádi, "The chemistry of natural diarylheptanoids," Structure and Chemistry (Part D), vol. 17, pp. 357-394, 1995.

[7] J. H. P. Tyman, Synthetic and Natural Phenols, Elsevier, New York, NY, USA, 1996.

[8] G. M. Keseru and M. Nogradi, Studies in Natural Products Chemistry, F. R. S. Atta-ur-Rahman, Ed., vol. 20, p. 263, Elsevier, New York, NY, USA, 1998.

[9] S. Quideau, Flavonoids: Chemistry, Biochemistry and Applications, Ø. M. Andersen and K. R. Markham, Eds., Taylor \& Francis Ltd., London, UK, 2006.

[10] M. C. Caruso, F. Galgano, M. Pecora, R. Tolve, M. Verrastro, and F. Favati, "Improvement of analytical methods for the determination of polyphenolic bioactive compounds in berry fruits," Journal of Chemistry, vol. 2015, Article ID 384051, 6 pages, 2015.

[11] M. D. Sintchak, M. A. Fleming, O. Futer et al., "Structure and mechanism of inosine monophosphate dehydrogenase in complex with the immunosuppressant mycophenolic acid," Cell, vol. 85, no. 6, pp. 921-930, 1996.
[12] J. M. Ferriz and J. Vinsova, "Prodrug design of phenolic drugs," Current Pharmaceutical Design, vol. 16, no. 18, pp. 2033-2052, 2010.

[13] B. Schmidt, F. Hölter, A. Kelling, and U. Schilde, "Pd-catalyzed arylation reactions with phenol diazonium salts: application in the synthesis of diarylheptanoids," The Journal of Organic Chemistry, vol. 76, no. 9, pp. 3357-3365, 2011.

[14] S. Quideau, D. Deffieux, C. Douat-Casassus, and L. Pouységu, "Plant polyphenols: chemical properties, biological activities, and synthesis," Angewandte Chemie International Edition, vol. 50, no. 3, pp. 586-621, 2011.

[15] M. Chalal, D. Vervandier-Fasseur, P. Meunier, H. Cattey, and J. C. Hierso, "Syntheses of polyfunctionalized resveratrol derivatives using Wittig and Heck protocols," Tetrahedron, vol. 68 , no. 20, pp. 3899-3907, 2012.

[16] G. A. Guerrero-Vásquez, N. Chinchilla, J. M. G. Molinillo, and F. A. Macías, "Synthesis of bioactive speciosins G and P fromHexagonia speciosa," Journal of Natural Products, vol. 77, no. 9, pp. 2029-2036, 2014.

[17] S. Yaqub, U. Farooq, A. Shafi et al., "Chemistry and Functionality of Bioactive Compounds Present in Persimmon," Journal of Chemistry, vol. 2016, Article ID 3424025, 13 pages, 2016.

[18] Y.-M. Zhang and C. O. Rock, "Evaluation of epigallocatechin gallate and related plant polyphenols as inhibitors of the FabG and FabI reductases of bacterial type II fatty-acid synthase," Journal of Biological Chemistry, vol. 279, no. 30, pp. 3099431001, 2004.

[19] G. Bringmann, T. Gulder, T. A. M. Gulder, and M. Breuning, "Atroposelective total synthesis of axially chiral biaryl natural products," Chemical Reviews, vol. 111, no. 2, pp. 563-639, 2011.

[20] S. E. Allen, R. R. Walvoord, R. Padilla-Salinas, and M. C. Kozlowski, "Aerobic copper-catalyzed organic reactions," Chemical Reviews, vol. 113, no. 8, pp. 6234-6458, 2013.

[21] J. H. Kim, N. Mahoney, K. L. Chan, R. J. Molyneux, and B. C. Campbell, "Secondary metabolites of the grapevine pathogen eutypa lata inhibit mitochondrial respiration, based on a model bioassay using the yeast Saccharomyces cerevisiae," Current Microbiology, vol. 49, no. 4, pp. 282-287, 2004.

[22] H. Matsuda, T. Kageura, M. Oda, T. Morikawa, Y. Sakamoto, and M. Yoshikawa, "Effects of constituents from the bark of Magnolia obovata on nitric oxide production in lipopolysaccharide-activated macrophages," Chemical \& Pharmaceutical Bulletin, vol. 49, no. 6, pp. 716-720, 2001.

[23] K.-T. Liou, Y.-C. Shen, C.-F. Chen, C.-M. Tsao, and S.-K. Tsai, "The anti-inflammatory effect of honokiol on neutrophils: mechanisms in the inhibition of reactive oxygen species production," European Journal of Pharmacology, vol. 475, no. 1-3, pp. 19-27, 2003.

[24] F. Amblard, B. Govindarajan, B. Lefkove et al., "Synthesis, cytotoxicity, and antiviral activities of new neolignans related to honokiol and magnolol," Bioorganic \& Medicinal Chemistry Letters, vol. 17, no. 16, pp. 4428-4431, 2007.

[25] Y. Fukuyama, K. Nakade, Y. Minoshima, R. Yokoyama, H. Zhai, and Y. Mitsumoto, "Neurotrophic activity of honokiol on the cultures of fetal rat cortical neurons," Bioorganic \& Medicinal Chemistry Letters, vol. 12, no. 8, pp. 1163-1166, 2002.

[26] T. Esumi, G. Makado, H. Zhai, Y. Shimizu, Y. Mitsumoto, and Y. Fukuyama, "Efficient synthesis and structure-activity relationship of honokiol, a neurotrophic biphenyl-type neolignan," Bioorganic \& Medicinal Chemistry Letters, vol. 14, no. 10, pp. 2621-2625, 2004. 
[27] M. Fotti, M. Piattelli, M. Z. Baratta, and G. Ruberto, "Flavonoids, coumarins, and cinnamic acids as antioxidants in a micellar system. Structure-activity relationship," Journal of Agriculture \& Food Chemistry, vol. 44, no. 2, pp. 497-501, 1996.

[28] R. Chirinos, D. Campos, N. Costa, C. Arbizu, R. Pedreschi, and Y. Larondelle, "Phenolic profiles of andean mashua (Tropaeolum tuberosum Ruíz \& Pavón) tubers: identification by HPLC-DAD and evaluation of their antioxidant activity," Food Chemistry, vol. 106, no. 3, pp. 1285-1298, 2008.

[29] S. Kiokias, T. Varzakas, and V. Oreopoulou, "In vitro activity of vitamins, flavonoids, and natural phenolic antioxidants against the oxidative deterioration of oil-based systems," Critical Reviews in Food Science and Nutrition, vol. 48, no. 1, pp. 78-93, 2008.

[30] C.-M. Chen and Y.-C. Liu, "A concise synthesis of honokiol," Tetrahedron Letters, vol. 50, no. 10, pp. 1151-1152, 2009.

[31] F. Shahidi and A. Chandrasekara, "Hydroxycinnamates and their in vitro and in vivo antioxidant activities," Phytochemistry Reviews, vol. 9, no. 1, pp. 147-170, 2010.

[32] M. Sova, "Antioxidant and antimicrobial activities of cinnamic acid derivatives," Mini-Reviews in Medicinal Chemistry, vol. 12, pp. 749-767, 2012.

[33] M. Liaudanskas, K. Zymone, J. Viškelis, A. Klevinskas, and V. Janulis, "Determination of the phenolic composition and antioxidant activity of pear extracts," Journal of Chemistry, vol. 2017, Article ID 7856521, 9 pages, 2017.

[34] D.-G. Yu and Z.-J. Shi, "Mutual activation: suzuki-miyaura coupling through direct cleavage of the sp2 C-O bond of naphtholate," Angewandte Chemie International Edition, vol. 50, no. 31, pp. 7097-7100, 2011.

[35] J. Cornella, C. Zarate, and R. Martin, "Metal-catalyzed activation of ethers via C-O bond cleavage: a new strategy for molecular diversity," Chemical Society Reviews, vol. 43, no. 23, pp. 8081-8097, 2014.

[36] S. Z. Tasker, E. A. Standley, and T. F. Jamison, "Recent advances in homogeneous nickel catalysis," Nature, vol. 509, no. 7500, pp. 299-309, 2014.

[37] Y. E. Lee, T. Cao, C. Torruellas, and M. C. Kozlowski, "Selective oxidative homo- and cross-coupling of phenols with aerobic catalysts," Journal of the American Chemical Society, vol. 136, no. 19, pp. 6782-6785, 2014.

[38] M. Tobisu and N. Chatani, "Cross-couplings using aryl ethers via C-O bond activation enabled by nickel catalysts," Accounts of Chemical Research, vol. 48, no. 6, pp. 1717-1726, 2015.

[39] H. Zeng, Z. Qiu, A. Domínguez-Huerta, Z. Hearne, Z. Chen, and C.-J. Li, "An adventure in sustainable cross-coupling of phenols and derivatives via carbon-oxygen bond cleavage," ACS Catalysis, vol. 7, no. 1, pp. 510-519, 2017.

[40] T. Osako, D. Panichakul, and Y. Uozumi, "Enantioselective carbenoid insertion into phenolic O-H bonds with a chiral copper(I) imidazoindolephosphine complex," Organic Letters, vol. 14, no. 1, pp. 194-197, 2012.

[41] S. Wang, P. Li, L. Yu, and L. Wang, "Sequential and one-pot reactions of phenols with bromoalkynes for the synthesis of (Z)-2-Bromovinyl phenyl ethers and benzo[b]furans," Organic Letters, vol. 13, no. 22, pp. 5968-5971, 2011.

[42] C. Li, Y. Zhang, P. Li, and L. Wang, "Palladium-catalyzed oxidative cyclization of 3-phenoxyacrylates: an approach to construct substituted benzofurans from phenols," The Journal of Organic Chemistry, vol. 76, no. 11, pp. 4692-4696, 2011.

[43] B. Xiao, T.-J. Gong, Z.-J. Liu et al., "Synthesis of dibenzofurans via palladium-catalyzed phenol-directed $\mathrm{C}-\mathrm{H}$ activation/C-O cyclization," Journal of the American Chemical Society, vol. 133, no. 24, pp. 9250-9253, 2011.

[44] B. Gabriele, R. Mancuso, G. Salerno, and M. Costa, "Cascade reactions: sequential homobimetallic catalysis leading to benzofurans and $\beta, \gamma$-unsaturated esters," Advanced Synthesis \& Catalysis, vol. 348, no. 9, pp. 1101-1109, 2006.

[45] M. M. Biddle, M. Lin, and K. A. Scheidt, "Catalytic enantioselective synthesis of flavanones and chromanones," Journal of the American Chemical Society, vol. 129, no. 13, pp. 3830-3831, 2007.

[46] Z.-W. An, M. Catellani, and G. Paolo Chiusoli, "Palladiumcatalyzed synthesis of aurone from salicyloyl chloride and phenylacetylene," Journal of Organometallic Chemistry, vol. 397, no. 3, pp. 371-373, 1990.

[47] Q. Yang and H. Alper, "Synthesis of chromones via palladium-catalyzed ligand-free cyclocarbonylation ofo-iodophenols with terminal acetylenes in phosphonium salt ionic liquids," The Journal of Organic Chemistry, vol. 75, no. 3, pp. 948-950, 2010.

[48] J. Ferguson, F. Zeng, and H. Alper, "Synthesis of coumarins via Pd-catalyzed oxidative cyclocarbonylation of 2-vinylphenols," Organic Letters, vol. 14, no. 21, pp. 5602-5605, 2012.

[49] D. A. Barancelli, A. G. Salles, J. G. Taylor, and C. R. D. Correia, "Coumarins from free ortho-hydroxy cinnamates by heckmatsuda arylations: a scalable total synthesis of (R)-Tolterodine," Organic Letters, vol. 14, no. 23, pp. 6036-6039, 2012.

[50] M. J. McKay, B. D. Naab, G. J. Mercer, and H. M. Nguyen, "Selective formation of $\beta$-O-aryl glycosides in the absence of the $\mathrm{C}(2)$-ester neighboring group," The Journal of Organic Chemistry, vol. 74, no. 13, pp. 4705-4711, 2009.

[51] T. Matsuda, M. Shigeno, and M. Murakami, "Palladiumcatalyzed sequential carbon-carbon bond cleavage/formation producing arylated benzolactones," Organic Letters, vol. 10, no. 22, pp. 5219-5221, 2008.

[52] F. Shibahara, S. Kinoshita, and K. Nozaki, "Palladium(II)catalyzed sequential hydroxylation-carboxylation of biphenyl using formic acid as a carbonyl source," Organic Letters, vol. 6, no. 14, pp. 2437-2439, 2004

[53] A. G. Sergeev, T. Schulz, C. Torborg, A. Spannenberg, H. Neumann, and M. Beller, "Palladium-catalyzed hydroxylation of aryl halides under ambient conditions," Angewandte Chemie International Edition, vol. 48, no. 41, pp. 7595-7599, 2009.

[54] E. J. Rayment, N. Summerhill, and E. A. Anderson, "Synthesis of phenols via fluoride-free oxidation of arylsilanes and arylmethoxysilanes," The Journal of Organic Chemistry, vol. 77, no. 16, pp. 7052-7060, 2012.

[55] A. Tlili, N. Xia, F. Monnier, and M. Taillefer, "A very simple copper-catalyzed synthesis of phenols employing hydroxide salts," Angewandte Chemie International Edition, vol. 48, no. 46, pp. 8725-8728, 2009.

[56] C. W. Yu, G. S. Chen, C. W. Huang, and J. W. Chern, "Efficient microwave-assisted Pd-catalyzed hydroxylation of aryl chlorides in the presence of carbonate," Organic Letters, vol. 14, no. 14, pp. 3688-3691, 2012.

[57] J. Simon, S. Salzbrunn, G. K. Surya Prakash, N. A. Petasis, and G. A. Olah, "Regioselective conversion of arylboronic acids to phenols and subsequent coupling to symmetrical diaryl ethers," The Journal of Organic Chemistry, vol. 66, no. 2, pp. 633-634, 2001.

[58] J. Xu, X. Wang, C. Shao, D. Su, G. Cheng, and Y. Hu, "Highly efficient synthesis of phenols by copper-catalyzed oxidative hydroxylation of arylboronic acids at room temperature in water," Organic Letters, vol. 12, no. 9, pp. 1964-1967, 2010. 
[59] K. Inamoto, K. Nozawa, M. Yonemoto, and Y. Kondo, "Micellar system in copper-catalysed hydroxylation of arylboronic acids: facile access to phenols," Chemical Communications, vol. 47, no. 42, pp. 11775-11777, 2011.

[60] H. Yang, Y. Li, M. Jiang, J. Wang, and H. Fu, "General coppercatalyzed transformations of functional groups from arylboronic acids in water," Chemistry-A European Journal, vol. 17, no. 20, pp. 5652-5660, 2011.

[61] Y. Q. Zou, J. R. Chen, X. P. Liu et al., "Highly efficient aerobic oxidative hydroxylation of arylboronic acids: photoredox catalysis using visible light," Angewandte Chemie International Edition, vol. 50, pp. 1-6, 2011.

[62] A. Gogoi and U. Bora, "A mild and efficient protocol for the ipso-hydroxylation of arylboronic acids," Tetrahedron Letters, vol. 54, no. 14, pp. 1821-1823, 2013.

[63] K. Gogoi, A. Dewan, A. Gogoi, G. Borah, and U. Bora, "Boric acid as highly efficient catalyst for the synthesis of phenols from arylboronic acids," Heteroatom Chemistry, vol. 25, no. 2, pp. 127-130, 2014.

[64] K. Webb and D. Levy, "A facile oxidation of boronic acids and boronic esters," Tetrahedron Letters, vol. 36, no. 29, pp. 5117-5118, 1995.

[65] R. E. Maleczka Jr., F. Shi, D. Holmes, and M. R. Smith III, " $\mathrm{C}-\mathrm{H}$ activation/borylation/oxidation: a one-pot unified route to meta-substituted phenols bearing ortho-/paradirecting groups," Journal of the American Chemical Society, vol. 125, no. 26, pp. 7792-7793, 2003.

[66] R. Benjamin, B. R. Travis, B. P. Ciaramitaro, and B. Borhan, "Preparation of purified $\mathrm{KHSO}_{5} \cdot \mathrm{H}_{2} \mathrm{O}$ and $n \mathrm{Bu}_{4} \mathrm{NHSO}_{5}$ from oxone by simple and efficient method," European Journal of Organic Chemistry, vol. 20, pp. 3429-3934, 2002.

[67] E. Kianmehr, M. Yahyaee, and K. Tabatabai, "A mild conversion of arylboronic acids and their pinacolyl boronate esters into phenols using hydroxylamine," Tetrahedron Letters, vol. 48, no. 15, pp. 2713-2715, 2007.

[68] G. K. S. Prakash, S. Chacko, C. Panja et al., "Regioselective synthesis of phenols and halophenols from arylboronic acids using solid poly ( $\mathrm{N}$-vinylpyrrolidone)/hydrogen peroxide and poly (4-vinylpyridine)/hydrogen peroxide complexes," $\mathrm{Ad}$ vanced Synthesis \& Catalysis, vol. 351, no. 10, pp. 1567-1574, 2009.

[69] A. Gogoi and U. Bora, "An iodine-promoted, mild and efficient method for the synthesis of phenols from arylboronic acids," Synlett, vol. 23, no. 7, pp. 1079-1081, 2012.

[70] N. Mulakayala, K. M. K. Ismail, K. M. Kumar et al., "Catalysis by Amberlite IR-120 resin: a rapid and green method for the synthesis of phenols from arylboronic acids under metal, ligand, and base-free conditions," Tetrahedron Letters, vol. 53, no. 45, pp. 6004-6007, 2012.

[71] C. Zhu, R. Wang, and J. R. Falck, "Mild and rapid hydroxylation of aryl/heteroaryl boronic acids and boronate esters with N-oxides," Organic Letters, vol. 14, no. 13, pp. 3494-3497, 2012.

[72] D. S. Chen and J. M. Huang, "A mild and highly efficient conversion of arylboronic acids into phenols by oxidation with MCPBA," Synlett, vol. 24, no. 4, pp. 499-501, 2013.

[73] P. Gogoi, P. Bezboruah, J. Gogoi, and R. C. Boruah, "Ipsohydroxylation of arylboronic acids and boronate esters by using sodium chlorite as an oxidant in water," European Journal of Organic Chemistry, vol. 2013, no. 32, pp. 7291-7294, 2013.

[74] Y.-Q. Zou, J.-R. Chen, X.-P. Liu et al., "Highly efficient aerobic oxidative hydroxylation of arylboronic acids: photoredox catalysis using visible light," Angewandte Chemie International Edition, vol. 51, no. 3, pp. 784-788, 2012.

[75] S. D. Sawant, A. D. Hudwekar, K. A. Aravinda Kumar, V. Venkateswarlu, P. P. Singh, and R. A. Vishwakarma, "Ligand- and base-free synthesis of phenols by rapid oxidation of arylboronic acids using iron(III) oxide," Tetrahedron Letters, vol. 55, no. 4, pp. 811-814, 2014.

[76] K. Hosoi, Y. Kuriyama, S. Inagi, and T. Fuchigami, "Electrochemical hydroxylation of organoboron compounds," Chemical Communications, vol. 46, no. 8, pp. 1284-1286, 2010.

[77] H. Jiang, L. Lykke, S. Uttrup Pedersen, W.-J. Xiao, and K. Anker Jørgensen, "A practical electromediated ipso-hydroxylation of aryl and alkyl boronic acids under an air atmosphere," Chemical Communications, vol. 48, no. 57, pp. 7203-7205, 2012.

[78] C. A. Contreras-Celedón, L. Chacón-García, and N. J. LiraCorral, "An efficient synthesis of phenols via oxidative hydroxylation of arylboronic acids using $\left(\mathrm{NH}_{4}\right)_{2} \mathrm{~S}_{2} \mathrm{O}_{8}$," Journal of Chemistry, vol. 2014, Article ID 569572, 5 pages, 2014.

[79] M. Gohain, M. du Plessis, J. H. van Tonder, and B. C. B. Bezuidenhoudt, "Preparation of phenolic compounds through catalyst-free ipso-hydroxylation of arylboronic acids," Tetrahedron Letters, vol. 55, no. 13, pp. 2082-2084, 2014.

[80] E. Saikia, S. J. Bora, and B. Chetia, " $\mathrm{H}_{2} \mathrm{O}_{2}$ in WERSA: an efficient green protocol for ipso-hydroxylation of aryl/heteroarylboronic acidipso-hydroxylation of aryl/heteroarylboronic acid," RSC Advances, vol. 5, no. 124, pp. 102723-102726, 2015.

[81] S. Eramoni, C. Bolin, and S. J. Bora, "Ipso-hydroxylation of aryl/heteroarylboronic acids using WEBPA as a green catalyst," Letters in Organic Chemistry, vol. 13, no. 10, pp. 764-769, 2016.

[82] T. Begum, A. Gogoi, P. K. Gogoi, and U. Bora, "Catalysis by mont K-10 supported silver nanoparticles: a rapid and green protocol for the efficient ipso-hydroxylation of arylboronic acids," Tetrahedron Letters, vol. 56, no. 1, pp. 95-97, 2015.

[83] R. Borah, E. Saikia, S. J. Bora, and B. Chetia, "On-water synthesis of phenols using biogenic $\mathrm{Cu}_{2} \mathrm{O}$ nanoparticles without using $\mathrm{H}_{2} \mathrm{O}_{2}$," RSC Advances, vol. 6, no. 102, pp. 100443-100447, 2016.

[84] I. Saikia, M. Hazarika, N. Hussian, M. R. Das, and C. Tamuly, "Biogenic synthesis of $\mathrm{Fe}_{2} \mathrm{O}_{3} @ \mathrm{SiO}_{2}$ nanoparticles for ipso -hydroxylation of boronic acid in water," Tetrahedron Letters, vol. 58, no. 45, pp. 4255-4259, 2017.

[85] Y. Fang, R. Zhao, Y. Yao et al., "Trichloroacetonitrile as an efficient activating agent for the ipso-hydroxylation of arylboronic acids to phenolic compounds," Organic \& Biomolecular Chemistry, vol. 17, no. 32, pp. 7558-7563, 2019.

[86] T. M. Shaikh and F. E. Hong, "Efficient method for the oxidation of aldehydes and diols with tert-butylhydroperoxide under metal- and solvent-free conditions," Tetrahedron, vol. 69, pp. 8929-8935, 2013. 